\title{
Graves' disease after treatment with Alemtuzumab for multiple sclerosis
}

\author{
Elena Tsourdi, ${ }^{1}$ Matthias Gruber, ${ }^{1}$ Martina Rauner, ${ }^{1}$ Judith Blankenburg, ${ }^{2}$ \\ Tjalf Ziemssen, ${ }^{2}$ Lorenz C. Hofbauer ${ }^{1,3}$
}

${ }^{1}$ Division of Endocrinology, Diabetes, and Bone Diseases, Department of Medicine III, Technical University Medical Center (ET, MG, MR, LCH); ${ }^{2} M S$ Center, Center of Clinical Neuroscience, Technical University Medical Center (JB, TZ); ${ }^{3}$ Center of Regenerative Therapies Dresden (LCH); Dresden, Germany

\begin{abstract}
CONTEXT: Alemtuzumab, a humanized monoclonal antibody against CD52, is effective in the treatment of early relapsing-remitting multiple sclerosis (MS). Common adverse effects include an acute-phase reaction, infections and autoimmune diseases, including thyroid disorders. SETTING: Patients from two phase 3 trials (CARE MS 1 and 2, n=15) were studied in a clinical research center. PATIENTS: Five out of fifteen patients developed severe Graves' disease after a mean of 32 months following the first alemtuzumab treatment. MAIN OUTCOME MEASURES: Thyroid function tests and thyroid antibodies were assessed. In addition, endocrine tests and measurement of antibodies indicative of autoimmunity were performed. RESULTS: Of the five patients developing Graves' disease, four patients were initially treated with antithyroid drugs, whereas the fifth patient had mild and self-limiting hyperthyroidism. Of the four patients treated with antithyroid drugs, one is currently under medical treatment in a dose-reducing regimen, whereas three patients underwent near-total thyroidectomy 2, 12 and 16 months later. Two patients developed endocrine ophthalmopathy. Pituitary, adrenal and gonadal hormones were normal in all patients. While four out of five patients were positive for several other autoantibodies, none developed other autoimmune diseases. CONCLUSION: Since autoimmune thyroid disease is common after alemtuzumab treatment for MS, pretreatment screening and careful follow-up may allow for early diagnosis and treatment.
\end{abstract}

Key words: Alemtuzumab, Graves' disease, Multiple sclerosis

Address for correspondence:

Lorenz C. Hofbauer, MD, Division of Endocrinology, Diabetes, and Bone Diseases, Department of Medicine III,

Technical University Medical Center, Fetscherstr. 74, D-01307 Dresden, Germany,

Tel.: +49-351-458-3173, Fax: +49-351-458-5801,

E-mail: lorenz.hofbauer@uniklinikum-dresden.de

Received 31-10-13, Accepted 10-01-2014

\section{INTRODUCTION}

Alemtuzumab, a humanized monoclonal antibody against CD52, leads to depletion of B and T lymphocytes, thereby substantially modifying adaptive immunity. ${ }^{1}$ CD52 is a glycoprotein encoded by the CD52 gene in humans. It is the protein targeted by alemtuzumab and it is present on the surface of mature 
lymphocytes as well as in monocytes and dendritic cells. ${ }^{2}$ Alemtuzumab effectively decreases relapse rate and disability progression in early active relapsingremitting multiple sclerosis (MS). ${ }^{3}$ Recent studies have demonstrated the efficacy of alemtuzumab in treatment-naive patients and patients resistant to basic immunomodulatory treatment. ${ }^{4-6}$

Common adverse effects of alemtuzumab include an acute infusion reaction (90\%), increased infection rates $(67 \%)$ and thyroid autoimmune disease $(20 \%))^{3-5}$ Severe adverse effects such as immune thrombocytopenic purpura and Goodpasture syndrome have also been rarely reported. ${ }^{7,8}$ Thyroid disorders after alemtuzumab treatment are variable, ranging from transient abnormalities of thyroid function tests to severe Graves' hyperthyroidism. ${ }^{9}$ The mechanisms underlying these variable autoimmune disorders are largely unclear. Autoimmunity in the context of lymphopenia is a well-recognized entity, ${ }^{10}$ and patients with a genetic predisposition and greater propensity to T-cell apoptosis in response to alemtuzumab treatment may be more susceptible to Graves' disease. ${ }^{11}$

Here, we report on five patients with remittingrelapsing MS without prior personal or family history of thyroid disease who developed severe Graves' disease following alemtuzumab therapy. These five patients received alemtuzumab in the setting of two phase 3 trials (CARE MS 1 and 2). We review the history and comorbidities and discuss diagnostic features and therapeutic considerations.

\section{METHODS}

All patients had early active forms of relapsingremitting multiple sclerosis (RMMS) based on a high relapse rate and MRI lesion activity. The patients received alemtuzumab in the CARE MS 1 and 2 clinical studies (protocol numbers CAMMS32400507 and CAMMS323) and the CAMMS03409 extension study. None of the patients had a prior history of thyroid disease. Thyroid function tests were monitored quarterly as part of the protocol. A comprehensive history and physical examination assessed risk factors for autoimmune disease, comorbidities and medications. Laboratory evaluation included a complete blood count, renal and liver function tests, thyroid function tests, antibodies against thyrotropin receptor (TSHR), thyroglobulin (Tg) and thyroperoxidase (TPO), and serum levels of calcium, phosphate, sodium, potassium, glucose and parathyroid hormone. In addition, basal pituitary, adrenal and gonadal hormones were analyzed and a detailed immunological profile was conducted. The diagnosis of Graves' was based on typical clinical findings and thyroid function tests, positive TSHR antibodies and characteristic ultrasound findings. ${ }^{12}$ All patients were evaluated for the presence of endocrine opthalmopathy using the CAS activity and severity score. ${ }^{13}$

\section{CASE PRESENTATION}

\section{Case 1}

A 35-year-old man was diagnosed with MS in 2006 after an optic neuritis and a cerebellar relapse. Immunomodulatory treatment included glatiramer acetate and interferon- $\beta 1 \mathrm{~b}$. As he suffered severe relapses from 2007 to 2009 that required high doses of methylprednisolone, alemtuzumab treatment was commenced in 2009. In 2012, 28 months after the first alemtuzumab exposure, the patient was referred for evaluation of hyperthyroidism (Table 1). Thyroid function tests revealed a TSH of $<0.01 \mathrm{mU} / 1$ (normal range: $0.3-4.2$ ), fT3 of $38 \mathrm{pmol} / 1$ (normal range: 2.8-7.1) and fT4 of $85 \mathrm{pmol} / 1$ (normal range: 11-22) with positive TSHR and Tg antibodies (Table 3). Furthermore, positive insulin antibodies $(3.1 \mathrm{U} / \mathrm{ml}$, normal $<2.4 \mathrm{U} / \mathrm{ml}$ ) were found. However, antibodies against islet cells, tyrosine phosphatase and glutamate decarboxylase were negative and biochemical studies excluded the presence of diabetes mellitus. The diagnosis of Graves' disease was based on clinical and laboratory findings and ultrasound findings of inhomogeneous thyroid parenchyma and marked hyperperfusion (Table 2). Treatment with thiamazol (40 $\mathrm{mg}$ per day) and propranolol (20 mg 3 times per day) was started. One year later, the patient is euthyroid while on $15 \mathrm{mg}$ of thiamazol per day. Several efforts to taper the dose have led to recurrent hyperthyroidism and definitive treatment is currently being discussed.

\section{Case 2}

A 31-year-old woman was diagnosed with MS after an optic neuritis and detection of gadoliniumenhancing lesions in a brain MRI in 2006. Interferon$\beta 1 \mathrm{~b}$ was started; however, she presented with relapses 
Table 1. General characteristics of five patients with Graves' disease after alemtuzumab therapy

\begin{tabular}{|c|c|c|c|c|c|c|}
\hline Case & $\begin{array}{l}\text { Gender \& } \\
\text { Age (yrs) }\end{array}$ & EDSS & Prior MS therapy & Other medication & Comorbidities & $\begin{array}{l}\text { Interval to onset } \\
\text { (months) }\end{array}$ \\
\hline 1 & $\mathrm{M} / 35$ & 3.5 & $\begin{array}{l}\text { Prednisolone } \\
\text { Interferon b-1a } \\
\text { Glatirameracetate } \\
\text { Amitriptyline }\end{array}$ & $\begin{array}{l}\text { Levetiracetam } \\
\text { Tolperison } \\
\text { Gabapentin }\end{array}$ & Arterial hypertension & 28 \\
\hline 2 & $\mathrm{~F} / 30$ & 1.5 & $\begin{array}{l}\text { Prednisolone } \\
\text { Plasmapheresis }\end{array}$ & None & None & 38 \\
\hline 3 & $\mathrm{~F} / 34$ & 4 & Prednisolone & $\begin{array}{l}\text { Citalopram } \\
\text { Omeprazol }\end{array}$ & None & 28 \\
\hline 4 & $\mathrm{M} / 38$ & 2 & $\begin{array}{l}\text { Prednisolone } \\
\text { Interferon } b-1 a\end{array}$ & None & None & 23 \\
\hline 5 & $\mathrm{~F} / 47$ & 3 & $\begin{array}{l}\text { Prednisolone } \\
\text { Interferon } b-1 a\end{array}$ & $\begin{array}{l}\text { Mirtazapine } \\
\text { Zopiclon } \\
\text { Gabapentin }\end{array}$ & Anxiety disorder & 44 \\
\hline
\end{tabular}

MS: multiple sclerosis, EDSS: expanded disability status scale.

Table 2. Diagnostic findings and therapy of five patients with Graves' disease after alemtuzumab therapy

\begin{tabular}{|c|c|c|c|c|c|c|c|c|}
\hline Case & $\begin{array}{l}\text { Thyroid } \\
\text { volume }(\mathrm{ml})\end{array}$ & US pattern & Smoking & EO & Medication & $\begin{array}{l}\text { Duration of medical } \\
\text { therapy (months) }\end{array}$ & $\begin{array}{l}\text { Adverse } \\
\text { effects }\end{array}$ & $\begin{array}{l}\text { Definitive } \\
\text { treatment }\end{array}$ \\
\hline 1 & 29 & Inhomogeneous & yes & no & $\begin{array}{l}\text { Thiamazol, } \\
\text { propanolol }\end{array}$ & 12 & None & - \\
\hline 2 & 29 & Inhomogeneous & no & yes & $\begin{array}{l}\text { Thiamazol, } \\
\text { propanolol }\end{array}$ & 12 & Vasculitis & Thyroidectomy \\
\hline 3 & 13 & Inhomogeneous & yes & no & Thiamazol & 16 & Alopecia & Thyroidectomy \\
\hline 4 & 52 & Inhomogeneous & yes & yes & $\begin{array}{l}\text { Thiamazol, } \\
\text { propanolol }\end{array}$ & 2 & Exanthema & Thyroidectomy \\
\hline 5 & 9 & Homogeneous & no & no & None & - & None & - \\
\hline
\end{tabular}

EO: endocrine ophthalmopathy, US: ultrasound.

Table 3. Thyroid function tests of five patients with Graves' disease after alemtuzumab therapy

\begin{tabular}{|c|c|c|c|c|c|c|}
\hline $\begin{array}{l}\text { Value } \\
\text { (Unit) }\end{array}$ & $\begin{array}{c}\text { TSH } \\
(\mathrm{mU} / \mathrm{l})\end{array}$ & $\begin{array}{c}\text { fT3 } \\
\text { (pmol/l) }\end{array}$ & $\begin{array}{c}\text { fT4 } \\
(\mathrm{pmol} / \mathrm{l})\end{array}$ & $\begin{array}{c}\text { TSHR-Ab } \\
\text { (U/l) }\end{array}$ & $\begin{array}{c}\text { TPO-Ab } \\
\text { (U/ml) }\end{array}$ & $\begin{array}{l}\text { Tg-Ab } \\
(\mathrm{U} / \mathrm{ml})\end{array}$ \\
\hline 1 & $<0.01$ & 38 & 85 & 8 & $>3000$ & 89 \\
\hline 2 & $<0.01$ & 32 & 65 & 12 & 93 & 89 \\
\hline 3 & $<0.01$ & 25 & 44 & 39 & 38 & 73 \\
\hline 4 & $<0.01$ & $>50$ & $>100$ & 22 & $>3000$ & 30 \\
\hline 5 & $<0.01$ & 7.8 & 26 & 3 & 489 & 962 \\
\hline Reference range & $0.3-4.2$ & $2.8-7.1$ & $12-22$ & $<1$ & $<60$ & $<60$ \\
\hline
\end{tabular}

TSH: thyroid-stimulating hormone, fT3: free triiodothyronine, fT4: free thyroxine, TSHR-Ab: antibodies against TSH receptor, TPO$\mathrm{Ab}$ : antibodies against thyreoidaseperoxidase, Tg-Ab: antibodies against thyroglobulin.

including optic neuritis and sensory symptoms over the next 2 years requiring methylprednisolone pulse therapy and plasmapheresis as well as alemtuzumab in 2009 (Table 1). Thirty-eight months after the first alemtuzumab treatment the patient presented with hyperthyroidism. Thyroid function tests demonstrated a TSH of $<0.01 \mathrm{mU} / 1$, fT 3 of $32 \mathrm{pmol} / 1$, and fT 4 of $65 \mathrm{pmol} / 1$ with positive antibodies against TSHR and 
$\mathrm{Tg}$ (Table 3). Further autoimmune screening showed positive antibodies against microsomal endoplasmic reticulum $(1: 80$, normal $<1: 20)$, whereas antimitochondrial antibodies and smooth muscle antibodies were negative and there was no evidence of autoimmune hepatitis. Mild endocrine ophthalmopathy was present with conjunctival injection and lid edema (CAS 2) and was treated locally with artificial tears. However, progressive ophthalmopathy (CAS 5) necessitated methylprednisolone pulse treatment resulting in marked improvement. Thiamazol $40 \mathrm{mg}$ per day and propranolol $20 \mathrm{mg}$ twice per day were started. After 3 weeks, the patient developed petechial exanthema on the lower limbs (Table 2). Complete blood count, plasmatic anticoagulation values and liver function tests were normal and the patient was treated with methylprednisolone topically which led to prompt improvement. Thiamazol was continued, but dose reduction repeatedly led to hyperthyroidism recurrence. Thus, she underwent near-total thyroidectomy 12 months after diagnosis of Graves' disease. She is currently euthyroid on $100 \mu \mathrm{g}$ levothyroxine per day.

\section{Case 3}

A 34-year-old woman was diagnosed with MS in 2004 after presenting with sensory symptoms. She did not receive any immunomodulatory treatment and remained stable until 2008, when she suffered three severe relapses involving the motor system during and after pregnancy. After delivery of a healthy child, alemtuzumab treatment was initiated in 2009; however, 28 months later the patient presented with clinical and biochemical hyperthyroidism (Table 1). Thyroid function tests were as follows: TSH $<0.01$ $\mathrm{mU} / 1$, fT3 $25 \mathrm{pmol} / 1$, fT4 $44 \mathrm{pmol} / 1$ with highly positive TSHR antibodies (Table 3 ). Further autoimmune screening showed positive parietal cell antibodies (82.7 $\mathrm{U} / \mathrm{ml}$, normal $<10 \mathrm{U} / \mathrm{ml}$ ), whereas all other antibodies were negative as was the complete blood count. Thiamazol treatment was begun at a dose of $20 \mathrm{mg}$ per day. Six months later and while the patient was euthyroid under thiamazol treatment, she developed patchy alopecia (Table 2). A topical mometasone treatment did not lead to significant improvement and repeated attempts to reduce the thiamazol dose resulted in recurrence of hyperthyroidism. Therefore, the patient underwent near-total thyroidectomy 16 months after the diagnosis of Graves' disease. She is currently euthyroid on $75 \mu \mathrm{g}$ levothyroxine per day.

\section{Case 4}

A 38-year-old man was diagnosed with MS in 2007 after presenting with optic neuritis two years earlier. In 2007, four relapses required methylprednisolone pulse therapy in addition to interferon- $\beta 1$ a IM (Table 1). In the CARE-MS 2 study, he received interferon$\beta 1$ a SC for several relapses over two years until he received alemtuzumab treatment in 2010 as part of the extension trial. Twenty-three months after the first alemtuzumab treatment, the patient presented with severe hyperthyroidism. Thyroid function tests demonstrated a TSH of $<0.01 \mathrm{mU} / 1$, fT3 $>50 \mathrm{pmol} / 1$, fT4 $>100 \mathrm{pmol} / 1$ with positive TSHR and Tg antibodies (Table 3). Further autoimmune screening showed positive insulin antibodies $(2.9 \mathrm{U} / \mathrm{ml}$, normal $<2.4$ $\mathrm{U} / \mathrm{ml}$ ). Antibodies against islet cells, tyrosine phosphatase and glutamate decarboxylase were negative and biochemical studies excluded the presence of diabetes mellitus. The diagnosis of Graves' disease was based on clinical and biochemical findings and a diffusely enlarged thyroid gland with marked hyperperfusion on ultrasound (Table 2). Mild endocrine ophthalmopathy was present with lid retraction (CAS 1) and was treated locally with artificial tears. Severe hyperthyroidism was treated with thiamazol $40 \mathrm{mg}$ twice per day and propranolol $40 \mathrm{mg}$ three times per day. Three weeks after initiation of thiamazol treatment, the patient developed a maculopapular palmar rash and elevated liver function tests. A topical treatment with methylprednisolone led to considerable improvement. However, in light of the need for long-term therapy, the patient preferred and underwent near-total thyroidectomy and is currently euthyroid on $125 \mu \mathrm{g}$ levothyroxine per day.

\section{Case 5}

A 47-year-old woman was diagnosed with MS in 2006 based on cerebellar symptoms after sensory symptoms had occurred in 2005. She was started on interferon- $\beta 1$ a IM, but after two relapses changed to alemtuzumab in 2008 (Table 1). Forty-four months after the first alemtuzumab treatment, the patient presented with biochemical values of mild hyperthyroidism. Thyroid function tests demonstrated a TSH of $<0.01 \mathrm{mU} / 1$, fT3 of $7.8 \mathrm{pmol} / 1$, and fT 4 of 26 $\mathrm{pmol} / \mathrm{l}$ with positive TSHR and Tg antibodies (Table 
3). Further autoimmune screening showed marginally positive islet cell and 21-hydroxylase antibodies (both 1:10, normal $<1: 10$ ), whereas antibodies against insulin, tyrosine phosphatase and glutamate decarboxylase were negative. Blood glucose, HbA1c, ACTH and cortisol levels were normal. The patient had no eye complaints and no symptoms of hyperthyroidism. Furthermore, thyroid ultrasound revealed no abnormalities and she was followed at regular intervals without specific therapy (Table 2). Peripheral thyroid hormones have spontaneously normalized, while TSH is still suppressed. The patient is currently without specific medication and is followed up at regular intervals.

\section{DISCUSSION}

We present a series of patients with MS who developed Graves' disease after treatment with alemtuzumab, an antibody directed against CD52. Our study reveals several important facts. First, the sex distribution did not follow the known pattern of female predominance in autoimmune thyroid diseases, as $40 \%$ were men. Sex hormones modulate various aspects of the immune system, but the molecular mechanisms underlying their effects are not fully understood. ${ }^{14}$ In thyroid autoimmune disease, an androgen-mediated decrease of thyrocyte expression of HLA class I and class II antigens has been implicated as a potential mechanism for female susceptibility. ${ }^{15}$ In addition, women are known to demonstrate a Th2-predominant immune response leading to an increased activation of B-cells and autoantibody production. Thus, although women are generally more prone to develop autoimmune thyroid diseases, equal gender distribution in this study may suggest different mechanisms in the pathogenesis of Graves' disease after alemtuzumab therapy. ${ }^{16}$ Studies with a higher number of patients are needed, however, to clarify this.

Second, the clinical course was characterized by poor response to antithyroid drugs ( 3 cases), side effects of antithyroid drug therapy ( 3 cases) and the presence of endocrine ophthalmopathy (2 cases). Therefore, definitive surgical treatment at an early stage was required in three of five patients in our study. We speculate that the production of autoantibodies against TSHR, perhaps mediated via increased numbers of memory-like T cells, is more robust and sustained after alemtuzumab than in patients with sporadic Graves' disease. ${ }^{17}$

Third, two of three patients with the most severe course of hyperthyroidism were active smokers, which underlines the adverse influence of smoking on the clinical course of Graves' disease and ophthalmopathy. ${ }^{18}$ Of note, two patients displayed high titers of antibodies against TSHR at initial evaluation, consistent with the correlation between TSHR antibody titers and Graves' ophthalmopathy ${ }^{19}$ and severity of Graves' hyperthyroidism, ${ }^{20}$ respectively.

The exact mechanisms underlying the development of Graves' hyperthyroidism after alemtuzumab treatment have been discussed in a recent review. ${ }^{21}$ In addition to thyroid-specific autoantibodies, the role of regulatory T-cells (Tregs) in autoimmune thyroid diseases has emerged. Since Tregs have immunomodulatory properties and can counteract the pro-inflammatory actions of Th1 and Th2 cells, a dysbalance of Tregs may favor Graves' hyperthyroidism through a permissive effect on the production of TSHR antibodies. ${ }^{21,22}$

In addition, patients with MS who developed autoimmunity showed more than 2-fold higher serum IL-21 levels compared to patients with no autoimmunity. ${ }^{23}$ This may increase the frequency of IL-21 receptor-positive effector T cells, which thereby have an increased probability of encountering thyroidspecific self-antigens and generating self-reactive $\mathrm{T}$ cells. While lymphocyte depletion and cytokine induction by alemtuzumab are mediated by neutrophils and natural killer cells, ${ }^{24}$ the proportion of intrathyroidal natural killer cells is decreased in patients with Graves' disease. ${ }^{25}$ Thus, peripheral activation of natural killer cells after alemtuzumab treatment may deplete the thyroid gland of these cells, rendering it more susceptible to autoimmunity. However, these immunological alterations require prospective in vivo validation in patients with MS who receive alemtuzumab treatment.

Based on our limited personal experience, we recommend pretreatment screening and continued follow-up with thyroid function tests and autoimmune profile in patients with MS treated with alemtuzumab. Patients with risk factors such as smoking or elevated 
titers of antithyroid antibodies may be at particular risk for severe disease. This strategy has been part of the alemtuzumab study protocol and will be implemented after its approval.

\section{DECLARATION OF INTEREST}

LCH has received honoraria from Amgen, Merck, Novartis and Nycomed. TZ has received honoraria from Almirall, Bayer Healthcare, Biogen, Merck, Sanofi/Genzyme, Novartis, Synthon and Teva. ET, MG, MR and JB have nothing to disclose.

\section{FUNDING}

Dr. Hofbauer's research program is supported by grants from the Deutsche Forschungsgemeinschaft (HO 1875/8-2, HO 1875/12-1 and HO 1875/13-1).

\section{REFERENCES}

1. Thompson SA, Jones JL, Cox AL, Compston DA, Coles AJ, 2010 B-cell reconstitution and BAFF after alemtuzumab (Campath-1H) treatment of multiple sclerosis. J Clin Immunol 30: 99-105.

2. Buggins AG, Mufti GJ, Salisbury J, et al, 2002 Peripheral blood but not tissue dendritic cells express CD52 and are depleted by treatment with alemtuzumab. Blood 100: 1715-1720.

3. Coles AJ, Cox A, Le Page E, et al, 2006 The window of therapeutic opportunity in multiple sclerosis: evidence from monoclonal antibody therapy. J Neurol 253: 98108.

4. Coles AJ, Compston DA, Selmaj KW, et al, CAMMS 223 Trial Investigators, 2008 Alemtuzumab vs. interferon beta-1a in early multiple sclerosis. N Engl J Med 359: 1786-1801.

5. Cohen JA, Coles AJ, Arnold DL, et al, CARE-MS I investigators, 2012 Alemtuzumab versus interferon beta 1a as first-line treatment for patients with relapsingremitting multiple sclerosis: a randomised controlled phase 3 trial. Lancet 380: 1819-1828.

6. Coles AJ, Twyman CL, Arnold DL, et al, CARE-MS II investigators, 2012 Alemtuzumab for patients with relapsing multiple sclerosis after disease-modifying therapy: a randomized controlled phase 3 trial. Lancet 380: 1829-1839.

7. Hirst CL, Pace A, Pickersgill TP, et al, 2008 Campath $1-\mathrm{H}$ treatment in patients with aggressive remitting multiple sclerosis. J Neurol 255: 231-238.

8. Klotz L, Meuth SG, Wiendl H, 2012 Immune mechanisms of new therapeutic strategies in multiple sclerosisA focus on alemtuzumab. Clin Immunol 142: 25-30.
9. Coles AJ, Wing M, Smith S, et al, 1999 Pulsed monoclonal antibody treatment and autoimmune thyroid disease in multiple sclerosis. Lancet 354: 1691-1695.

10. Sherer Y, Shoenfeld Y, 1998 Autoimmune diseases and autoimmune post-bone marrow transplantation. Bone Marrow Transplant 22: 873-881.

11. Weetman AP, 2009 "Ioning out thyroid autoimmunity". Endocr Pract 15: 53-55.

12. Sipos JA, Kahaly GJ, 2012 Imaging of thyreotoxicosis. Am J Med 125: 1-2.

13. Wiersinga WM, Perros P, Kahaly GJ, et al, 2006 Clinical assessment of patients with Graves' orbitopathy: the European Group on Graves' Orbitopathy recommendations to generalists, specialists and clinical researchers. Eur J Endocrinol 155: 387-389.

14. Castagnetta L, Granata OM, Traina A, et al, 2002 A role for sex steroids in autoimmune diseases: a working hypothesis and supporting data. Ann NY Acad Sci 966: 193-203.

15. Estienne V, Duthoit C, Reichert M, et al, 2002 Androgen-dependent expression of FCgammaRIIB2 by thyrocytes from patients with autoimmune Graves' disease: a possible molecular clue for sex dependence of autoimmune disease. FASEB J 16: 1087-1092.

16. Fairweather D, Frisancho-Kiss S, Rose NR, 2008 Sex differences in autoimmune disease from a pathological perspective. Am J Pathol 173: 600-609.

17. Pearl JP, Parris J, Hale DA, et al, 2005 Immunocompetent T-cells with a memory-like phenotype are the dominant cell type following antibody-mediated T-cell depletion. Am J Transplant 5: 465-474.

18. Bahn RS, 2010 Graves' ophthalmopathy. N Engl J Med 362: 726-738.

19. Eckstein A, Esser J, Mann K, Schott M, 2010 Clinical value of TSH receptor antibodies measurement in patients with Graves' orbitopathy. Pediatr Endocrinol Rev 7: Suppl 2: 198-203.

20. Iglesias P, Devora O, Garcia J, et al, 2010 Severe hyperthyroidism: aetiology, clinical features and treatment outcome. Clin Endocrinol 72: 551-557.

21. Aranha AA, Amer S, Reda ES, et al, 2013 Autoimmune Thyroid Disease in the Use of Alemtuzumab for Multiple Sclerosis: A Review. Endocr Pract 11: 1-25.

22. Glick AB, Wodzinski A, Fu P, et al, 2013 Impairment of regulatory $\mathrm{T}$ cell function in autoimmune thyroid disease. Thyroid 23: 871-878.

23. Jones JL, Phuah CL, Cox AL, et al, 2009 IL-21 drives secondary autoimmunity in patients with multiple sclerosis, following therapeutic lymphocyte depletion with alemtuzumab (Campath-1H). J Clin Invest 119: 2052-2061.

24. Hu Y, Turner MJ, Shields J, et al, 2009 Investigation of the mechanism of action of alemtuzumab in a human CD52 transgenic mouse. Immunology 128: 260-270.

25. Watanabe M, Nakamura Y, Matsuzuka F, et al, 2008 Decrease of intrathyroidal CD161+Valpha24+Vbeta11+ NKT cells in Graves' disease. Endocr J 55: 199-203. 